\title{
Paleogeographic Reconstitution and Tangential Tectonic in the Backland of Tunisian Dorsal (Fahs Area: J. Rouas and Ruissate)
}

\author{
Aymen Arfaoui 1,2*, Kais Aridhi², Sabri Aridhi ${ }^{3}$, Mohamed Ghanmi², Fouad Zargouni2 \\ ${ }^{1}$ Service Géologique, Office National des Mines (ONM), Tunis, Tunisie \\ ${ }^{2}$ Unité de Recherche Géomantique, Géologie Structurale et Appliquée, Faculté des Sciences de Tunis, \\ Université Tunis-El Manar, Campus Universitaire, Tunis, Tunisie \\ ${ }^{3}$ Entreprise Tunisienne d'Activités Pétrolière (ETAP), Tunis, Tunisie \\ Email: *arfawiaymen@gmail.com, aridhikais@gmail.com, sabriaridhi@gmail.com, \\ ghanmi.mohamed@gmail.com, fouadzargouni@yahoo.fr
}

Received 21 December 2015; accepted 27 February 2016; published 2 March 2016

Copyright (C) 2016 by authors and Scientific Research Publishing Inc.

This work is licensed under the Creative Commons Attribution International License (CC BY). http://creativecommons.org/licenses/by/4.0/

(c) () Open Access

\section{Abstract}

The Tunisian Dorsal backland is the Eastern Atlas side of maghrebides. Field data of Fahs area allowed us to develop new interpretations and to characterize the main structural features of the studied devices (Jebel Rouas and Ruissate). Heritage of Zaghouan accident, Triassic salt movements and strike-direction of major synsedimentary faults are the principal causes and results of the skinned and superimposed geometric architecture, generated by the reversed extensional (Jurassic-Cretaceous) tectonics. The actual geometry of Jebel Rouas and Ruissate represents a fault propagation fold, affecting Jurassic and Cretaceous sets. The backland of this thrust fault defines an imbrications structures of Barremian series. Tectonic records activities show the existence of angular unconformities (Oligocene and Eocene series on the Cretaceous sets considered as bedrock), slumps, tectonic breccias and synsedimentary faults are all of them controlled by a deep major accident; N-S to NE-SW and NW-SE. Features of the study area are probably related first; to the blockage of Zaghouan thrust oriented NE-SW in the foreland; then, to the intense halokinetic activity, which facilitates the layers displacement acting as decollment level. The detailed structural and stratigraphic study of Fahs area and its neighbors shows the presence of an intense tangential tectonic during upper Miocene, affecting Meso-Cenozoic sets, because all the structures involved are sealed by Oligocene and Miocene thinned series. This is accentuated by the existence of different sets of decollment at different depths, which are represented by a displacement to the

"Corresponding author.

How to cite this paper: Arfaoui, A., Aridhi, K., Aridhi, S., Ghanmi, M. and Zargouni, F. (2016) Paleogeographic Reconstitution and Tangential Tectonic in the Backland of Tunisian Dorsal (Fahs Area: J. Rouas and Ruissate). International Journal of Geosciences, 7, 239-248. http://dx.doi.org/10.4236/ijg.2016.73019 
SE through the backland of the Tunisian Dorsal. We define these features as an imbrication and thrusting Out of sequence system.

\section{Keywords}

Tunisian Dorsal Backland, Paleogeographic Reconstitution, Unconformities, Synsedimentary Faults, Thrust Tectonic, Decollement Level, Ramp Folds, Fault Propagation Fold

\section{Introduction}

Northern Tunisia corresponds to the most eastern side of Maghrebides. Its orogeny is the result of a succession of compressive events (Alpine, Atlasic, and Villafranchian). This orogenic cycle is materialized in Tunisia by a geodynamic evolution called "Tunisian Atlas" (Figure 1(a)). Fahs area (domain of Jebel Ruissate and Rouas) is

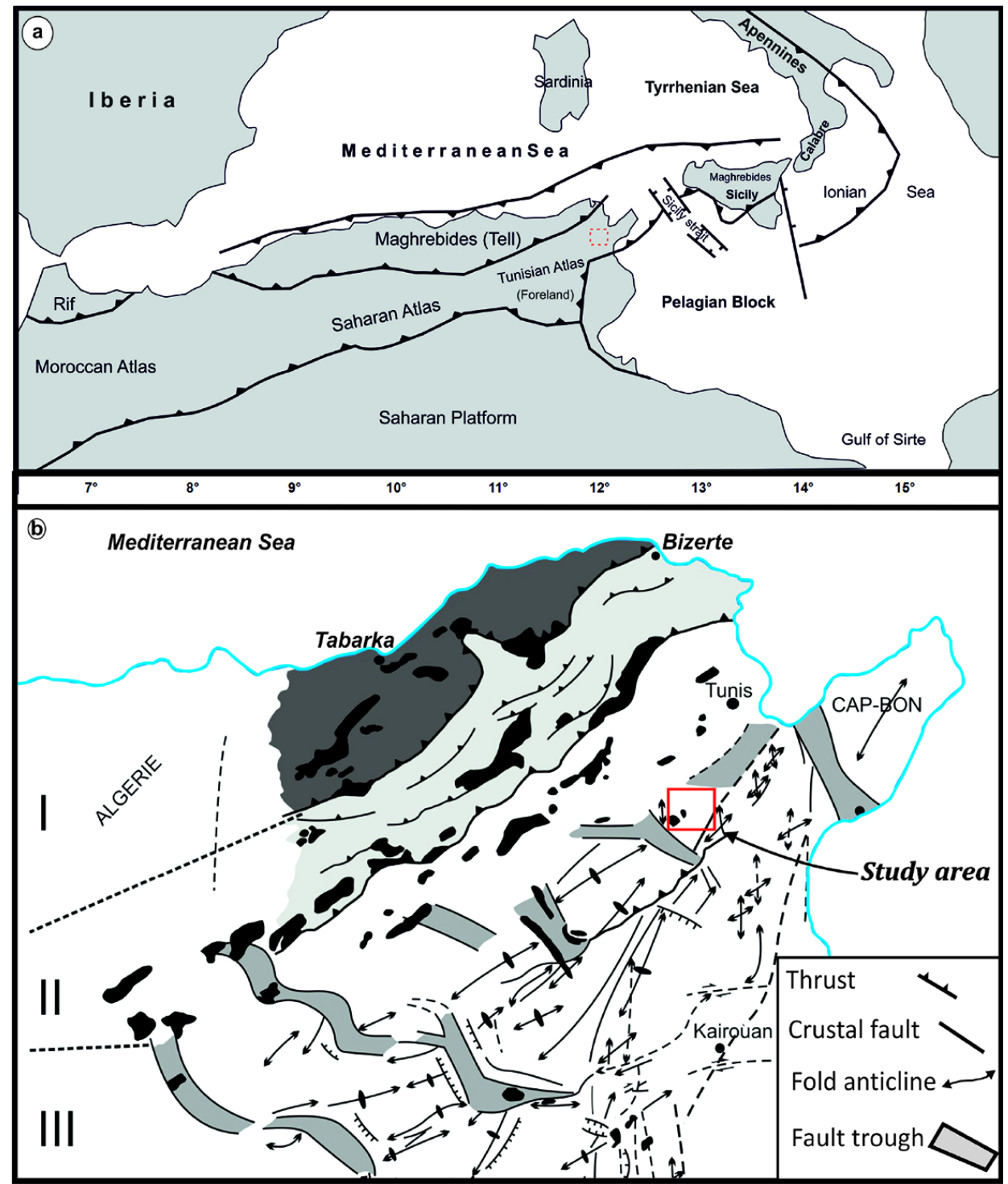

Figure 1. (a) A Schematic map of North Africa showing the main structural domains (Piqué et al. 1997), (b) the structural map of Tunisia (Zargouni, 1985, Ghanmi, 2003). 
one of the most geodynamic evolution witnesses. Those series retain polyphase tectonic activities and are the seat of several reverse events. It records a structural evolution from the Jurassic to the Quaternary affirming the extensional tectonic of Mesozoic and the compressive events during the Cenozoic. The study area is located in North-eastern Tunisia, covering an area of about 80 square kilometers. It's a part of the Tunisian oriental Atlas; the backland area of Tunisian Dorsal (Figure 1(b)). It is limited by the field of "diaper" [1]-[3] or "dome" [4] [5] or "salt-province" [6]-[12] in the north-western, by the accident of Zaghouan [13]-[15] in the south, and by the plain of Seminja in the East. It's characterized by folds oriented NNE-SSW which are parallel to Zaghouan accident [14]-[17] that corresponds to the major direction of the Atlasic folds. The Jurassic massive of Jebel Rouas is affected in the eastern part by a large thrust fault oriented N-S to NE-SW (Figure 2) facilitated by the salt Triassic decollement level [13]. It is a major accident in the cover structure which is probably rooted in the basement. This accident corresponds to the Jurassic lineament thrust on lower Cretaceous series [18]. The mapping revision based on new biostratigraphic dating of Cretaceous series and structural analysis proves the presence of an extensional heritage and has begun since the Jurassic. This extensional heritage is expressed by raised and collapsed blocks grafted to synsedimentary faults oriented NE-SW with NNW dip, which affects Cretaceous series. This half-graben with collapsed blocks is responsible for the structuring and the controlling of depositional process of sedimentary series in study area (Figure 4).

\section{Palaeogeography and Lithostratigraphic Data}

The study area presents a lithostratigraphic series, stretching from Triassic to Quaternary (Figure 3). It is characterized by stratigraphic gap and angular unconformity caused by Triassic salt movement and synsedimentary faults which control the Meso-Cenozoic sedimentary series (Figure 4). It's a thick, carbonate, and siliciclastic series which represent various lateral changes of facies and thicknesses. The lithological cross section of Jebel Rouas and Ruissate begins with a chaotic Triassic complex. It is composed by colored marls with gypsum, limestone, dolomite, and micaceous sandstone [19]. This Triassic complex is topped by dolomitic, graveleous,

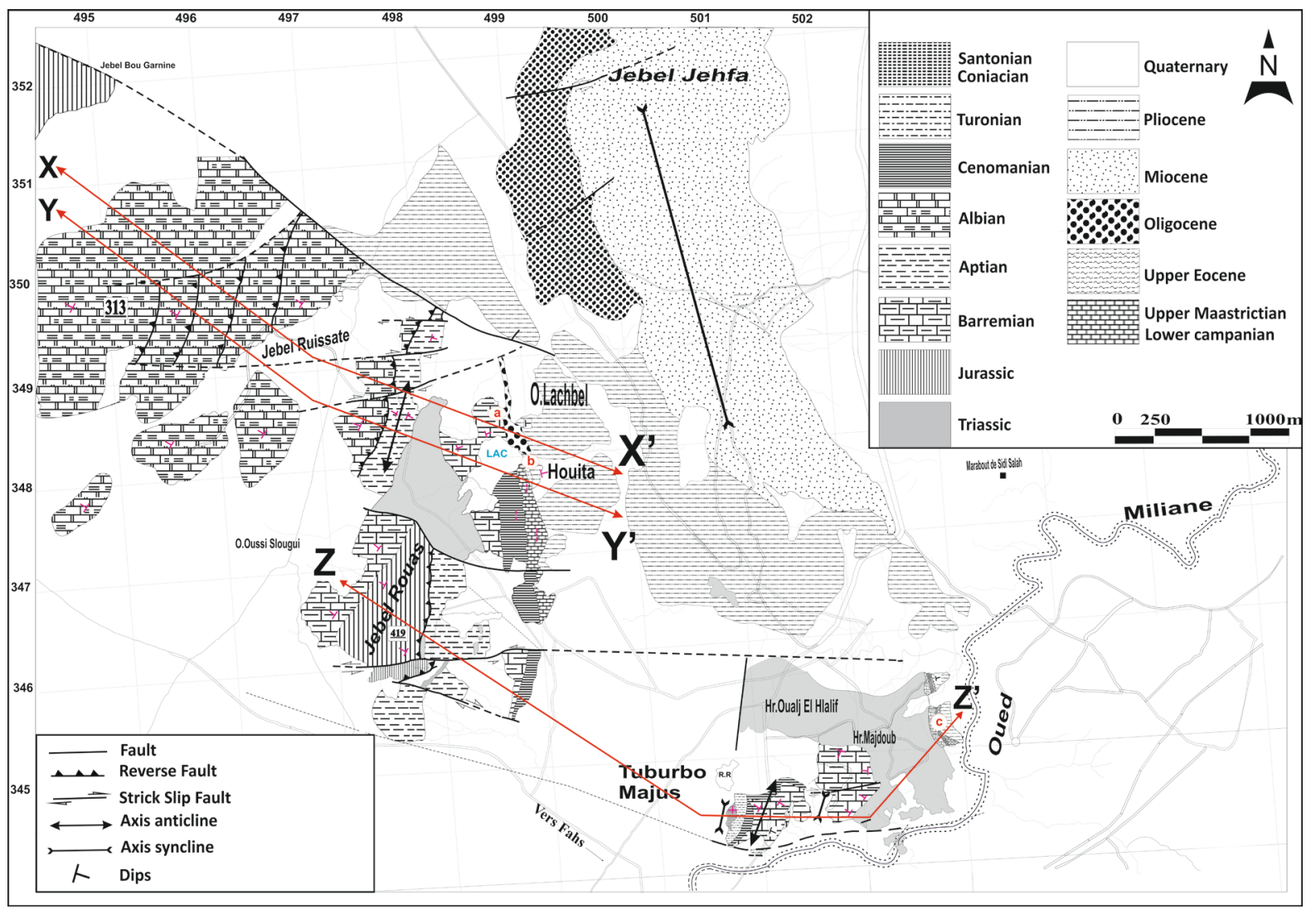

Figure 2. Geological map of Fahs area and position of structural cross-sections. 


\begin{tabular}{|c|c|c|c|}
\hline Age & Formation & Lithology & Lithostratigraphy \\
\hline $\begin{array}{l}\text { Quaternary } \\
\text { Plio- }\end{array}$ & & 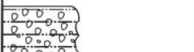 & Conglomerates \\
\hline $\begin{array}{l}\text { Miocene } \\
\text { Oligo- }\end{array}$ & & & $\begin{array}{l}\text { Grey and clay sandy } \\
\text { Thin sandy with a ripple cross } \\
\text { stratification }\end{array}$ \\
\hline $\begin{array}{l}\text { Upper } \\
\text { Eocène }\end{array}$ & Souar & & Yellow marls \\
\hline $\begin{array}{l}\text { Upper Maastrichtian } \\
\text { Lower Campanian- }\end{array}$ & Abiod & 婜 & $\begin{array}{l}\text { Chalky limestone with clay and } \\
\text { limestone interbeds }\end{array}$ \\
\hline $\begin{array}{l}\text { Santonian } \\
\text { Coniacian- }\end{array}$ & Aleg & & Dark green marl \\
\hline & & & Marl and limestone interbeds \\
\hline Turonian & Bahloul & & Marl and limestone \\
\hline $\begin{array}{l}\text { Cenomanian } \\
\text { Albian- }\end{array}$ & Fahdene & $100 \mathrm{~m}$ & Dark marls, marly-limestone \\
\hline Aptian & \multirow{2}{*}{ M'Chergua } & & Sansdstone, limestone and green marl \\
\hline Barremian & & & Marly-limestone and marls \\
\hline 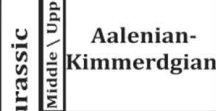 & & 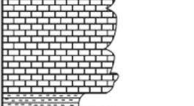 & Limestones and marls interbeds \\
\hline$=\begin{array}{ll}\text { Hetnagian- } \\
\text { sinemurian }\end{array}$ & Oust & 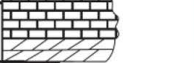 & Limestones and dolomites \\
\hline Triassic & & & $\begin{array}{l}\text { Colored marls with gypsum,Limestone, } \\
\text { dolomites, sandstone }\end{array}$ \\
\hline
\end{tabular}

Figure 3. Synthetic stratigraphic column of study area.

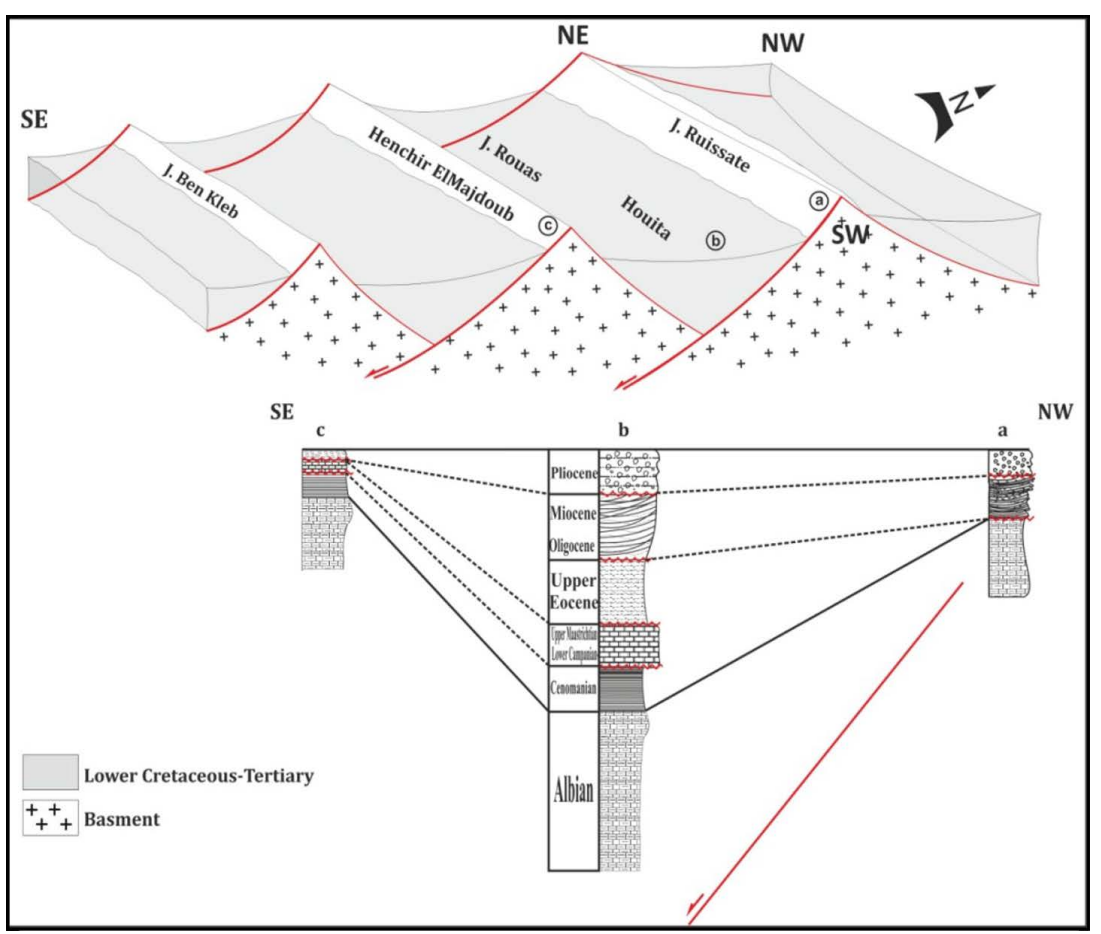

Figure 4. Sedimentary correlation of lower Cretaceous-Tertiary in generalized sections of the Jebel Ruissate, Jebel Rouas and Henchir El Majdoub: (a) geometric and paleogeographical evolution, (b) lithostratigraphic correlation. 
oncolytic and bioclastic limestones in the base of Lower Jurassic: Hettangian-Sinemurian (Oust formation), described by [20], then, with succession of marls and limestones of the Middle and Upper Jurassic: AalenianKimmeridgian [21]. The Lower Cretaceous series are represented by clays, marl, sandstone and limestone, while the Upper Cretaceous series are represented by dark marls, marly-limestone and centimetric to metric beds of limestone. During the Cretaceous period, there have been sudden changes of facies thickness, in pelagic basin, from SE to NW and gradual changes from NE to SW. The thickness's variation is symptomatic of an active extensional tectonics probably transtensive with a logic of collapsed blocks (Figure 4). These passages explain the presence of a fault oriented NE-SW limiting these two areas. The Paleogene reduced series are represented by clay Globigerina deposits in the Upper Eocene (Souar formation) which are based in angular unconformity with Cretaceous layers. This is shows the absence of all Paleocene (Haria formation) and Lower Eocene (Ypresian) series (Bou Dabbous formation). These missed series outcrop further in east of the study area (Jebel Houita Bou Ragouba) with very small thickness of about $7 \mathrm{~m}$ [15] [22]. Laterally, in the of Hammam Zriba structure, the lower Eocene (Metlaoui formation) shows $80 \mathrm{~m}$ of thickness. This gap origin to tectonic activity is the result of sedimentary control practiced by the major faults oriented NE-SW coupled at creeping of Triassic complex. The Neogene series are represented by thin sandy with a ripple cross stratification, grey and clay-sandy deposits in the Oligo-Miocene. The Quaternary is characterized by conglomerates.

\section{Structural Data and Discussions}

The study area shows the existence of intense deformation, materialized by overlaps, imbrications structures and folds which are generally associated. The major affected structures corresponding to Cretaceous-Tertiary age are formed by alternating marls, limestones, clays, dolomites and sandstone. These overlaps are fled under the Pliocene deposits (Figure 2).

\subsection{Ruissate Structure}

The cross section is localized in NW of study area (Figure 2), oriented NW-SE. it's represented by thick series, formed by alternating consistent limestones and schistose marls dating of Barremian age. This Barremian deposits thrusts an anticline formed by dark marls series corresponding to Aptian level (Figure 5(a), Figure 5(b)). Toward the SE (Houita region), the cross section shows the existence of Albian marls with $80^{\circ}$ dipping to the SE. The Cenomanian series is represented by alternating limestones and dark marls. These two series are overlapped by chalky limestones alternated with clear marls of Maastrichtian age with $75^{\circ}$ dipping. In fact, we note the presence of an irregular contact between Albian and Cenomanian. This gap of all series from Turonian to Campanian proves the existence of extensional tectonic events which makes this region like an uplift zone bring on by Apto-Albian phase. The brown clay Globigerina of upper Eocene series (Souar formation) is taking with an angular unconformity upon the chalky limestones of Maastrichtian age (Figure 5(a), Figure 5(b)). This unconformity was made as the upper Eocene compressive event; which has been observed and studied through outcrops by several authors [23]-[26] in different region (Zaghouan, Medjez El Bab and N-S axis). Further, in Eastern Tunisia, the subsurface shows the existence of this compressive phase by the seismic reflection methods expressed by reverse structures, thrusting, duplex and a successive unconformities as onlaps. Finally, the compressive atlasic event is materialized by a low angular unconformity which makes the Pliocene deposits in contact clay upper Eocene (Souar formation). This cross section proves the presence of thrusting structure of Barremian series on clay Aptian sets (decollment level) (Figure 5(a), Figure 5(b); Photo 2(a)). Moreover, we note the existence of many reverses faults affecting the marly limestones of Barremian series considered as intra-Barremian imbrications structures (Photo 2(b)). The actual geometry of Jebel Ruissate is considered as a dissymmetric fold: Fault propagation fold with an order of apparition which is opposite to stress direction witnessed as an out of sequence system (Photo 2(c)). We signalize the presence of extensional tectonic heritage materialized by [15] [17] [27] [28] which control the Cenozoic compressive evolution through the Mesozoic normal faults which determinate the nucleation of kink folds.

\subsection{Rouas Structure}

This cross section start with series formed by Albian limestones and marls reposed directly with a clear stratigraphic concordance on upper Jurassic marly limestones (Beni Kleb Formation) with $40^{\circ}$ dipping towards NW 


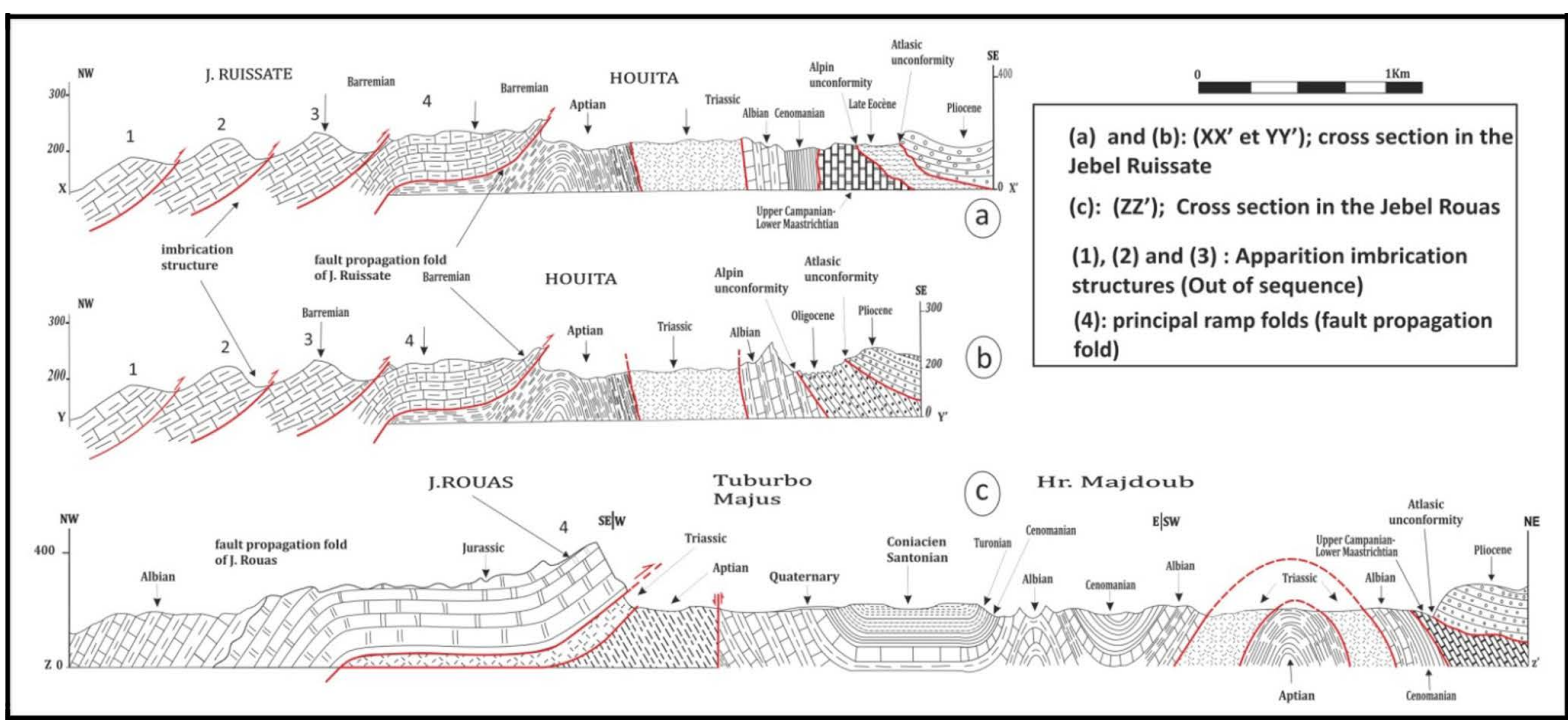

Figure 5. Geological cross-sections in the Jebel Ruissate and Jebel Rouas.

(Figure 5(c)). The massif of Jebel Rouas is considered as an uplift zone since the upper Jurassic [13]. This big gap of the lower cretaceous series shows the amplitude induced by faults oriented E-W to N100 - 110 and N-S to N30 - 40 faults during all cretaceous extensional period. The faults system is the result of a wide accident toward the east which is the Zaghouan thrust [15] [29]. Further, this deeps faults system causes the collapsing of the neighboring zones (Fahs through and Seminja plain). In the Jebel Rouas, the sedimentary series is affected by thrust-fault oriented N30 - 40 verging SE which makes in abnormal contact the Jurassic on the low cretaceous with $40^{\circ}$ dipping towards NW (Figure 5(c)). This thrust facilitated by the salt Triassic sets qualified as decollment level. A new filed observation and dating data allowed us to reinterpret the actual geometry of Jebel Rouas as dissymmetric folding structure oriented N-S to NNE-SSW. This structure begins after a shearing movement which displaces the series towards to SE [30]. This accident draws a form in "S" (Photo 1(a)) begins by a tangential movement in the base of series (Lower level of ramp). Moreover, this major thrust cutting the series with an angle of $45^{\circ}$ (ramp). Finally, the ramp (fault propagation fold) is become to horizontal at the top of hinge (upper level of ramp), displace it to the SE with "cut-off" truncation (Photo 1(b)). The geometry study of Jebel Rouas structure proves the existence of fault propagation fold (Photo 1(b)) proposed by [6] [23] [26] [27] [31]-[35] and reflects a kinematic evolution of displacement, described by a decollment level generally included in a ductile series.

\section{Interpretation and Kinematic Evolution}

The tectonic and kinematic evolution of the study area signalizes an accommodation epoch of the half-graben from Triassic to Oligocene. The study area knows a particular structuring essentially result of an extensional to transtensive system. In fact, the opening of the basin is controlled by synsedimentary faults oriented NNE-SSW verging north which influences the Meso-Cenozoic deposits. It forms eventually a succession model of ripples (crest) and basins (creux of half-graben). This model (Figure 4) is similar to the one which is described in the north of the thrust nappe front [31] [36]-[39]. During upper Eocene, the first compressive pulsation, qualified as tangential movement, leads to the imbrication of sedimentary series, expressed by several unconformities. This system is controlled by strike slip faults oriented N100 - 110 and reverse faults oriented N30 - 40 (Photo 1(a)). During their evolution, these structures are influenced by Triassic movement, which leads the formation of plate and ramp. During the upper Miocene a major compressive event, reversed faults strike direction N30-40 in thrust faults and it is responsible for the inversion of extensional structures. In the stage, we notes, the shortening is growing and the plate and ramp structures are accentuated and developed. The ramp fold explains the common association of asymmetrical folds with steep forelimbs adjacent to thrust faults [32]. Further, this reverse system is probably responsible for installation of back thrust structures (Houita region), which caused the blockage of the system and the formation of structures type "Out of sequence" (Photo 2) identified at Jebel 


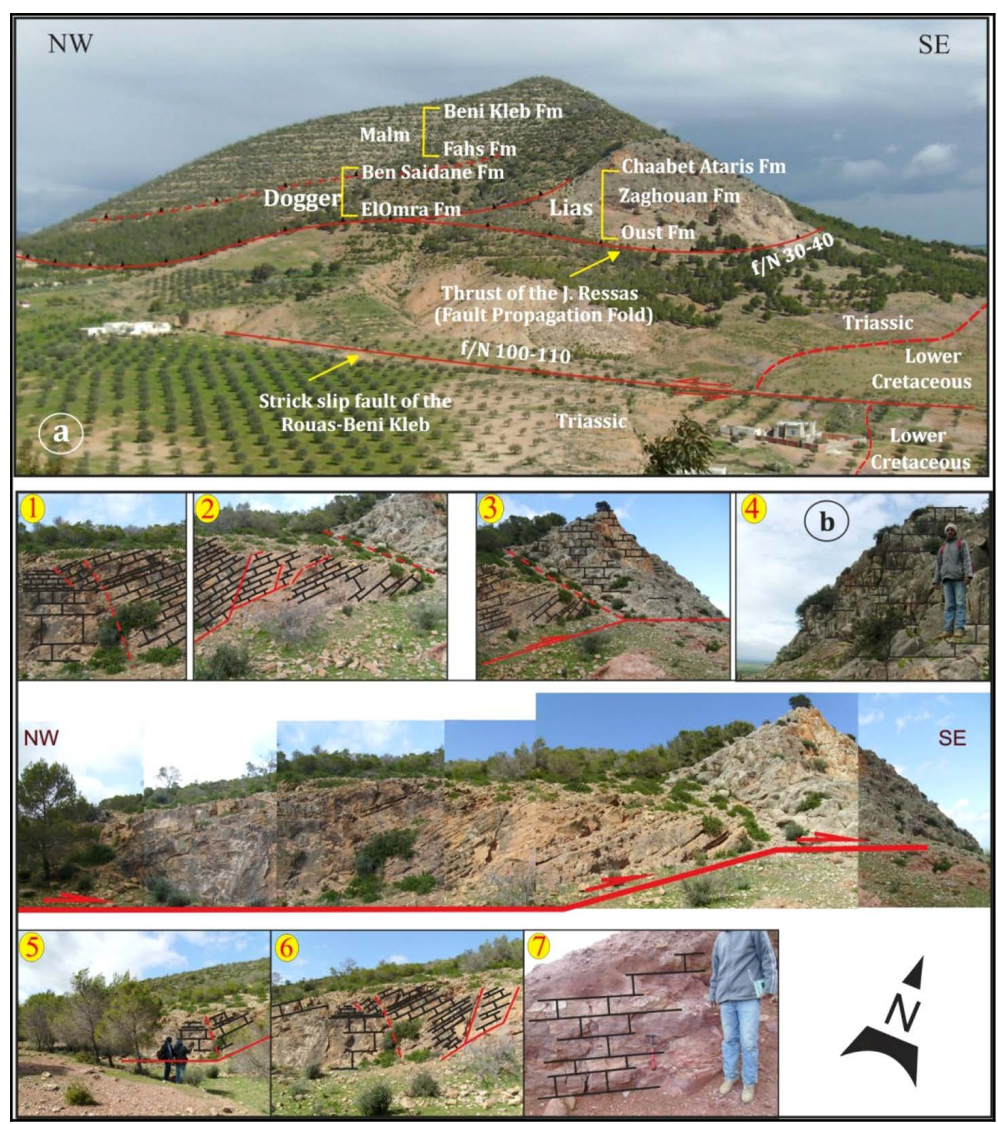

Photo 1. Kink geometrical structure of Jebel Rouas.
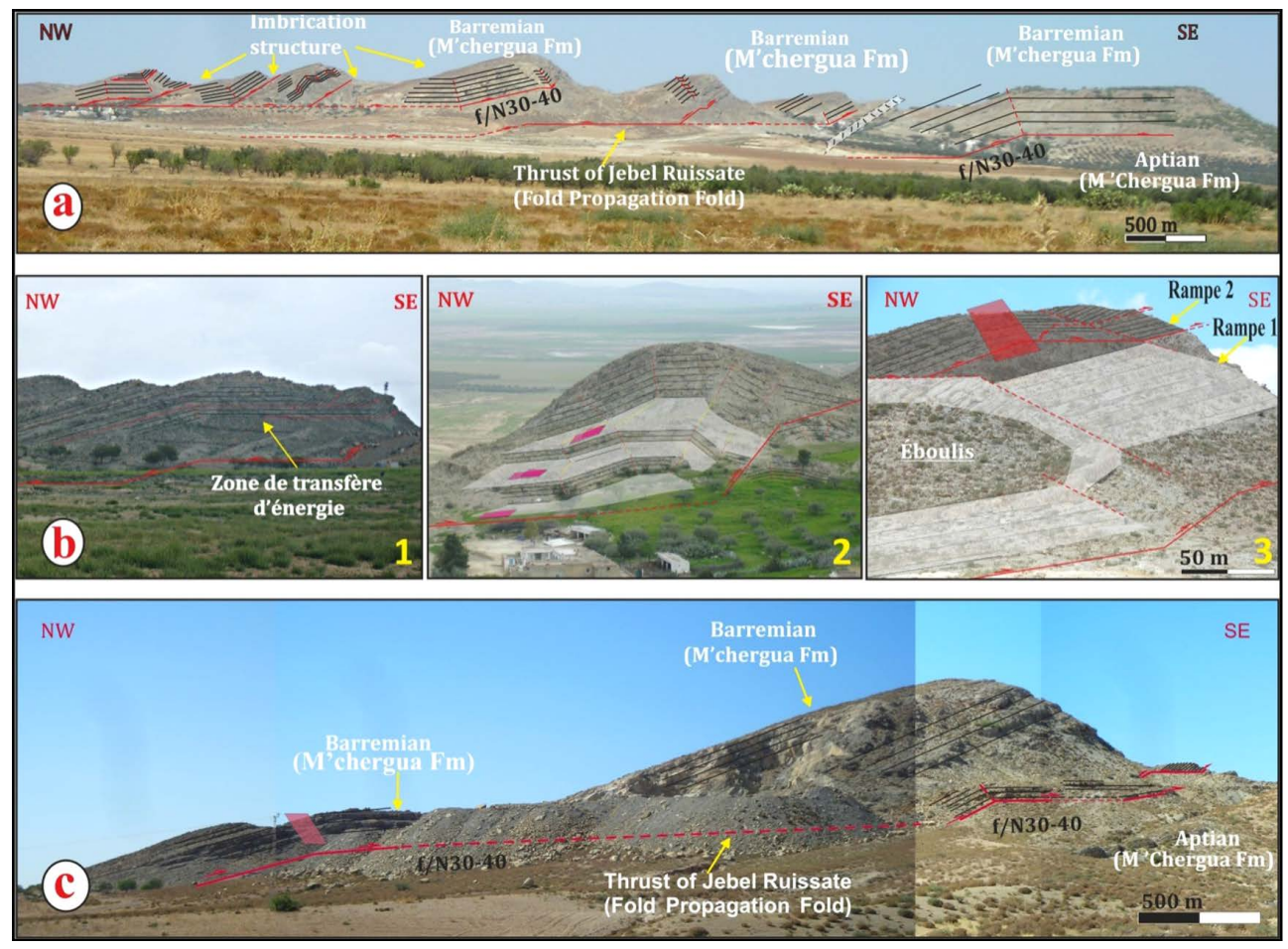

Photo 2. KinkGeometry of Jebel Ruissate with order apparition of out of sequence. 
Ruissate [32]. Eventually, these structures are folded with apparition a small flexural basins during the Plio-quaternary event.

\section{Conclusion}

The analysis and interpretation of field data prove the presence of a synsedimentary extensional heritage belongs the Mesozoic period, reversed by a compressive tectonics starting at upper Eocene pulsation and evolving at upper Miocene event and during Pliocene-Quaternary phase. We signalize the existence of an extensional tectonic heritage [15] [17] [27] [28] which controls the tertiary compressive evolution. Mesozoic normal faults, qualified as synsedimentary, determine the kink folds nucleation. In fact, these compressive events are responsible for the inversion tectonic of tertiary [15] [17] [31] [36]-[39]. Further, they are considered as the major cause that forms thrusting structures called fault propagation fold [23] [24] [27] [31]-[33] [35] [36] [39]-[50]. Their principal decollement levels are founded in Triassic level which migrates towards the upper ductile levels: in Aptian clay (M’Chergua formation), then Coniacian-Santonian marls (Aleg formation) and Paleocene marls (Haria formation). These thrusting structures are formed during the Eocene pulsation, evolved and probably blocked during the tortonian event proved by imbrications structures type "out of sequence" and installation of small flexural basins belongs the Plio-quaternary event. This dynamic is the origin of the actual geometry of study area.

\section{References}

[1] Bouaziz, S., Barrier, E., Soussi, M., Turki, M.M. and Zouari, H. (2002) Tectonic Evolution of the Northern African Margin in Tunisia from Pale Stress Data and Sedimentary Record. Tectonophysics, 357, 227-253. http://dx.doi.org/10.1016/S0040-1951(02)00370-0

[2] Htira, N. (2006) Le Trias salifère de l'extrémité orientale du Maghreb: Pétrogenèse, gisements minéraux et dynamique. Habilitation, Tunis El Manar University, Tunis.

[3] Perthuisot, V. (1978) Dynamique et pétrogenèse des intrusions triasiques en Tunisie septentrionale. Thèse. Docte, Es-Sci.Labo.Géol.E.N.S. Paris, 359 p.

[4] Bolze, J. (1954) Position stratigraphique des formations salifère dans l'extrême nord tunisien. Comptes Rendus Hebdomadaires des Séances de l'Académie des Sciences, 258, 4594 p.

[5] El Ouardi, H. (1996) Halocinèse et rôle des décrochements dans l'évolution géodynamique de la partie médiane de la zone des dômes (Tunisie septentrionale). Thèse Doct. Spé. Tunis, 242 p.

[6] Arfaoui, A. (2008) Tectonique Méso-Cénozoïque de la région de Pont de Fahs et ses environs (Tunisie Nord Orientale). Mastère. Géol., Univ. Tunis II, Fac. Sc. Tunis, 92 p, 53 fig.

[7] Ben Chalbi, M., Melki, F. and Zargouni, F. (2006) Mode de mise en place des corps salifères dans l'Atlas septentrional de Tunisie.

[8] Ghanmi, M., Ben Youssef, M., Jouirou, M., Zargouni, F. and Villa, J.M. (2001) Halocinèse crétacé au jebel Kebbouch (Nord-Ouest tunisien): Mise en place à fleur d'eau et évolution d'un "glacier de sel” albien, comparaisons. Eclogae Geologicae Helvetiae, 94,153-160.

[9] Ghanmi, M. (2003) Géodynamique de la plate-forme saharienne et sa marge septentrionale au Crétacé, son évolution vers l'Atlas septentrional; interférences du rifting et de l'Halocinèse; H. D. R., 347 p. Fac. Sci. Tunis.

[10] Masrouhi, A. (2006) Les appareils salifères des régions de Mateur, Tebourba et de Medjez El Bab (Tunisie du Nord), Thèse, Université Tunis El Manar, 258.

[11] Vila, J.M., Ben Youssef, M. and Masrouhi, A. (2002) La future “autoroute de l'ouest” de Tunis à Oued Zarga, recoupe un "glacier de sel” sous marin Albien à 5 km au SSE de Medjez El Bab: Observation, datations et gravimétrie. 2séminaire de stratigraphie, Algérie, 7-10 décembre 2002, 85-86.

[12] Vila, J.M., Ben Youssef, M., Chikaoui, M. and Ghanmi, M. (1996) Deuxième étude de surface d’un grand "glacier de sel” sous-marin Albien (250 km²); Les masses triasiques du “diapir” de Ben Gasseur et de l'anticlinal du Kef (NordOuest Tunisien). Bulletin de la Societe Geologique de France, 167, 235-246.

[13] Castany, G. (1955) Les extrusions Jurassiques en Tunisie. Annales des Mines et de la Géologie Tunisien, No. 14, 71 p.

[14] Jauzein, A. (1967) Contribution à l'étude géologique des confins de la dorsale tunisienne (Tunisie septentrionale). Annales des Mines et de la Géologie Tunisien, 4, 457 p.

[15] Turki, M.M. (1985) Polycinématique et contrôle sédimentaire associé sur la cicatrice Zaghouan-Nebhana. Thèse de Doctorat d’Etat, Université de Tunis, Tunis, 262. 
[16] Morgan, M.A., Grocott, J. and Moody, R.T.J. (1998) The Structural Evolution of the Zaghouan-Ressas Structural Belt, Northern Tunisia. In: Macgregor, D.S., Moody, R.T.J. and Clark-Lowes, D.D., Eds., Petroleum Geology of North Africa, The Geological Society, London, Special Publications No. 132, 405-422. http://dx.doi.org/10.1144/GSL.SP.1998.132.01.23

[17] Turki, M.M., Delteil, J., Truillet, R. and Yaich, C. (1988) Les inversions tectoniques de la Tunisie centro-septentrionale. Bulletin de la Societe Geologique de France, IV, 399-406.

[18] Solignac, M. (1927) Etude géologique de la Tunisie Septentrionale. Dir. Géo. Trav. Pub., Tunis, Thèse Doct. Es. Sci, Lyon.

[19] Zargouni, F. (1975) Etude géologique de la chaine Lansarine (région de Tebourba-Atlas tunisien). Thèse $3{ }^{\text {ème }}$ cycle, Université Pierre et Marie CURIE, Paris, 87 p.

[20] Soussi, M. (2003) Nouvelle nomenclature lithostratigraphique “évènementielle” pour le Jurassique de la Tunisie Atlasique. Géobios, 36, 761-773. http://dx.doi.org/10.1016/j.geobios.2003.03.001

[21] Rais, J. (1995) Géodynamique, paléoenvironnement et microfaciès du dépôt Jurassique en bordure Sud-est de la Téthys Magrébine. Thèse, Université de Tunis, Tunis, 255 p.

[22] Bajanik, S., Biely, A., Mencik, E., Salaj, J. and Stranik, Z. (1976) Carte géologique de la Tunisie à 1/50000 feuilles du Zaghouan-Notice Explicative. Publ. Serv. Géol. Tunisie, Tunis.

[23] Aridhi, S. (2013) Structural Context of Meso-Scale and Cartographical Duplex Structure Genesis in Thrusting Tectonics: Role of Tear Faults. Zaghouan Thrust Belt. Case of Bir M’Cherga-Ain Asker Area. Arabian Journal of Geosciences, 7, 2499-2514. http://dx.doi.org/10.1007/s12517-013-0955-9

[24] Masrouhi, A., Ghanmi, M., Ben Slama, M.M., Ben Youssef, M., Vila, J.M. and Zargouni, F. (2008) New tectonoSedimentary Evidence Constraining the Timing of the Positive Tectonic Inversion and the Eocene Atlasic phase in Northern Tunisia: Implication for the North African Paleo-Margin Evolution. Comptes Rendus Geosciences, 340, 771778. http://dx.doi.org/10.1016/j.crte.2008.07.007

[25] Ouali, J. and Mercier, E. (2007) The Neogene Structural Evolution of the Western Margin of the Pelagian Platform, Central Tunisia: Discussion. Journal of Structural Geology, 19, 1249-1252. http://dx.doi.org/10.1016/S0191-8141(97)00048-5

[26] Suppe, J. (1981) Mechanics of Mountain Building and Metamorphism in Taiwan. Memoir of the Geological Society of China, No. 4, 67-89.

[27] Creuzot, G., Mercier, E., Ouali, J. and Turki, M.M. (1992) Héritage distensif synsédimentaire et structuration chevauchante: Apport de la modélisation du chevauchement alpin de Zaghouan (Atlas Tunisien). Comptes Rendus de l'Académie des Sciences, Series II, 314, 961-965.

[28] Martin, J. and Mercier, E. (1996) Heritage distensif et structuration chevauchante dans une chaine de couverture; apport de l'equilibrage par modelisation geometrique dans le Jura nord-occidental. Bulletin de la Société Géologique de France, 167, 101-110.

[29] Morgan, M., Grocott, J. and Moody, R.T.J. (1992) The Structural Setting and Evolution of the Zaghouan-Ressas Structural Belt in the Zaghouan Area. Tunisian Atlas, Northern Tunisia, Memoires ETAP, Tunisia, (5), 193-209.

[30] Zargouni, F. (1985) Tectonique de l'Atlas méridional de Tunisie Evolution géométrique et cinématique des structures en zone de cisaillement. Doctorat d'Etat, Université Louis Pasteur, Strasbourg, 296 p.

[31] Aridhi, K. (2012) Reconstitution paléogéographique et tectonique tangentielle en plat et rampe des unités numidienne et sous-numidienne: Monts de Bou Heurtma-Béjaoua et Nefza (Tunisie Septentrionale). Thèse, Université Tunis El Manar, Tunis, 258.

[32] Mercier, E. and Mansy, L. (1995) Le blocage de transport sur le plat des plis de propagation: Une cause possible de chevauchement hors séquence. Geodinamica Acta, 8, 199-210. http://dx.doi.org/10.1080/09853111.1995.11417257

[33] Merle, O. (1994) Nappes et chevauchement, Paris, éd. MASSON, 285.

[34] Mitra, S. (1990) Fault Propagation Fold: Geometry, Kinematic Evolution and Hydrocarbon Traps. AAPG Bulletin, 74, 921-945.

[35] Suppe, J. (1983) Geometry and Kinematics of Fault-Bend Folding. American Journal of Science, 283, 684-721. http://dx.doi.org/10.2475/ajs.283.7.684

[36] Aridhi, K., Ould Bagga, M.A., Abdeljaouad, S., Zargouni, F. and Mercier, E. (2011) Lateral Ramp-Related Folding Evidences in the Tellian Domain of Tunisia: Tectonic Implications. Comptes Rendus Geosciences, 343, 360-369. http://dx.doi.org/10.1016/j.crte.2011.03.004

[37] Aridhi, K., Aridhi, S., Ould Bagga, M.A., Abdeljaouad, S., Zargouni, F. and Mercier, E. (2011) Paleogeographical Restoration and Ramp Tectonic Evidence in Tunisian Tellian Domain: Ain El Bey-Bou Awen Area. Arabian Journal of Geosciences, 6, 1591-1599. http://dx.doi.org/10.1007/s12517-011-0447-8 
[38] Ould Bagga, M.A. (2003) Evolution tectono-sedmentaire et analyse structurale d'un segment des Maghrebides orientales: La région de Ghardimaou-Fernana (Tunisie Nord-occidentale). Thèse de $3^{\text {ème }}$ cycle, Univ. Tunis II, Faculté des Sciences de Tunis, Tunis, $507 \mathrm{p}$.

[39] Ould Bagga, M.A., Abdeljaouad, S. and Mercier, E. (2006) La “zone des nappes” de Tunisie: Une marge mésocénozoïque en blocs basculés modérément inversée (région de Tabarka/Jendouba; Tunisie nord-occidentale). Bulletin de la Societe Geologique de France, 177, 145-154. http://dx.doi.org/10.2113/gssgfbull.177.3.145

[40] Anderson, J.E. (1996) The Neogene Structural Evolution of the Western Margin of the Pelagian Plateforme, Central Tunisia. Journal of Structural Geology, 18, 819-835. http://dx.doi.org/10.1016/S0191-8141(96)80015-0

[41] Ben Chilla, L., Guilhaumou, N., Mougin, P., Jaswal, T. and Roure, F. (2003) Reconstruction of Paleo-Burial History and Pore Fluid Pressure in Foothill Areas: A Sensitivity Test in the Hammam Zriba (Tunisia) and Koh-i-Maran (Pakis$\tan$ ) ore deposits. Geofluids, 3, 103-123. http://dx.doi.org/10.1046/j.1468-8123.2003.00053.x

[42] Ben Romdhan, M., Brahim, N., Ouali, J. and Mercier, E. (2006) Tectonique quaternaire et plis de rampe dans le golfe d'Hammamet (Offshore tunisien). Comptes Rendus Geosciences, 338, 341-348. http://dx.doi.org/10.1016/j.crte.2006.02.001

[43] Mercier, E. (1992) Une évolution possible des chevauchements associés aux plis de propagation: Le transport sur le plat (modélisation et exemple). Bulletin de la Societe Geologique de France, 163, 713-720.

[44] Mercier, E., Outtani, F. and Frizon De Lamotte, D. (1997) Late Stage Evolution of Fault-Propagation Folds: Principales and Exemple. Journal of Structural Geology, 19, 185-193. http://dx.doi.org/10.1016/S0191-8141(96)00081-8

[45] Mercier, E. (1995) Les plis de propagation de rampe: Cinématique, modélisation et importance dans la tectonogenèse. Habilitation à diriger des recherches, Université de Cergy-Pontoise, Cergy-Pontoise, 175 p.

[46] Martinez, C. and Truillet, R. (1987) Évolution structurale et paléogéographie de la Tunisie. Memoria de la Societa Italiana de Geologia, 38, 35-45. http://dx.doi.org/10.1144/GSL.SP.1998.132.01.23

[47] Piqué, A., Tricart, P., Guiraud, R., Laville, E., Bouaziz, S., Amrhar, M. and Aitouali, R. (2002) The Mesozoic-Cenozoic Atlas Belt (North Africa): On Overview. Geodinamica Acta, 15, 185-208. http://dx.doi.org/10.1016/s0985-3111(02)01088-4

[48] Wilkerson, M.S., Apotria, T. and Farid, T. (2002) Interpreting the Geologic Map Expression of Contractional FaultRelated Fold Terminations: Lateral Oblique Ramps versus Displacement Gradients. Journal of Structural Geology, 24, 593-607. http://dx.doi.org/10.1016/S0191-8141(01)00111-0

[49] Wilkerson, M.S. and Medwedeff, D.A. (1991) Geometrical Modeling of Fault Related Folds: A Pseudo Three-Dimensional Approach. Journal of Structural Geology, 13, 801-812. http://dx.doi.org/10.1016/0191-8141(91)90005-4

[50] Wilkerson, M.S., Smaltz, S.M., Bowman, D.R., Fischer, M.P. and Higuera-Diaz, I.C. (2006) 2-D and 3-D Modeling of Detachment Folds with Hinterland Inflation: A Natural Example from the Monterrey Salient, Northeastern Mexico. Journal of Structural Geology, 29, 73-85. http://dx.doi.org/10.1016/j.jsg.2006.07.010 